\title{
Hybrid learning environments: a significant contribution to the development of technological and collaborative skills in university teachers
}

\section{Entornos híbridos de aprendizaje: una contribución significativa al desarrollo de competencias tecnológicas y colaborativas en el profesorado universitario}

\author{
DOI: $10.46932 / \mathrm{sfjdv2n4-075}$
}

Received in: May 1st, 2021

Accepted in: Jun 30th, 2021

\author{
María del Carmen Jiménez Barriosnuevo \\ Universidad Popular del Cesar \\ Colombi \\ E-mail: mariacjimenez@unicesar.edu.co \\ Malio Fernando Bolivar Palacio \\ Universidad Popular del Cesar \\ Colombia \\ E-mail: maliobolivar@unicesar.edu.co
}

\begin{abstract}
This document intends to show the impact of training in b-learning through MOODLE in the development of technological and collaborative skills in higher education teachers, based on the evident lack of teacher training in the use and appropriation of ICT at the Universidad Popular del Cesar (UPC). In order to do this, a research with a quantitative approach of a pre-experimental type with a pre-test-post-test design with a group was necessary, at a descriptive study level, using two surveys as data collection instruments, one to identify the level of knowledge of the educators on the use of technologies and collaborative skills in higher education and the other one to determine the teacher's perception about the use of technologies and collaborative skills in higher education. In the study, teachers of the pedagogy department intervened with hours of direct classes. The results and conclusions established that there was little use of the technological space, and integration of ICT in the teaching practice. Also, that the influence of training under Moodle in the development of technological skills and collaborative skills was positive.
\end{abstract}

Key words: Digital skills, computer literacy, collaborative skills, blended learning, Moodle

\section{RESUMEN}

El presente documento pretende mostrar el impacto de la formación en b-learning a través de MOODLE en el desarrollo de competencias tecnológicas y colaborativas en docentes de educación superior, a partir de la evidente falta de formación docente en el uso y apropiación de las TIC en la Universidad Popular del Cesar (UPC). Para ello, fue necesario realizar una investigación con enfoque cuantitativo de tipo preexperimental con un diseño pre-test-post-test con un grupo, a nivel de estudio descriptivo, utilizando como instrumentos de recolección de datos dos encuestas, una para identificar el nivel de conocimiento de los educadores sobre el uso de las tecnologías y las habilidades colaborativas en la educación superior y otra para determinar la percepción del docente sobre el uso de las tecnologías y las habilidades colaborativas en la educación superior. En el estudio intervinieron profesores del departamento de pedagogía con horas de clases directas. Los resultados y conclusiones establecieron que había poco uso del espacio tecnológico, y la integración de las TIC en la práctica docente. También, que la influencia de la formación bajo Moodle en el desarrollo de las competencias tecnológicas y de las competencias colaborativas fue positiva. 
Palabras clave: Competencias digitales, alfabetización informática, competencias colaborativas, formación semipresencial, Moodle

\section{INTRODUCTION}

The digital era constantly encourages teachers to incorporate ICT in the training process, but technologies alone are not a guarantee of bringing improvements to education, it must exist a curricular planning, where new pedagogical strategies are formulated and didactic materials are incorporated. To this end, the Colombian government has created policies that favor open access to digital content and programs to help educators integrate ICT in the classroom. However, there is a considerable waste of technological resources in the schools, which requires a continuous and updated technological training in teachers. Zabala and Arnau (2007) ensure that many educators do not have the competencies to incorporate technology efficiently in a specific context.

Taking into consideration the above-mentioned, this document presents an investigation carried out with the aim of determining the impact of online training through Moodle on UPC teachers, in addition to knowing the potential and difficulties regarding the development of technological and collaborative skills in order to improve the planning of future trainings intended for teachers

\section{LITERATURE REVIEW}

\subsection{TECHNOLOGICAL SKILLS: ESSENTIAL FOR TEACHING}

Education in the $21^{\text {st }}$ century requires teachers to know how, when, and where to use technology, which is why different policies that promote the use of ICT at an international level, emphasize that educators and students must have digital skills. In the past, it was enough to know how to handle computer equipment in educational institutions. Jara (2013) states that it is important to achieve skills to solve problems related to the management of ICT, in other words, to pursue, analyze, separate, synthesize, represent, and produce information in the digital environment.

In the same way, Tejada (2009) states that the skills that a teacher must have to achieve an effective performance in their job are: planning of teaching-learning processes, preparation of disciplinary content, presentation of information in an organize and understandable way, ICT management, methodological design, vertical and horizontal communication, evaluation, research on teaching and teamwork.

Based on that, this study focused on the use of new technologies by the teacher, knowing that the use of ICT in training and the teaching practice of the educator forces them to put into practice a series of new or complementary skills in their academic exercise, allowing them a better development in class, which favors him on a professional and personal level, and gives students the opportunity to have a more 
up-to-date, dynamic training in accordance with the global changes imposed by technology

\subsection{COLLABORATIVE SKILLS: A KEY ELEMENT IN TEACHING PRACTICE}

According to Alfaro (2010, paragraph. 1), collaborative skills are defined as "the ability to interact and promote synergies with the members of a group, in activities that allow achieving certain objectives in a more effective and efficient way than if the activity was done individually". These types of skills facilitate the development of a flexible and dynamic educational model, capable of adapting to the continuous flow of information and characteristic events of the information society.

At the same time, the conception of learning has been changing from a static model to a more dynamic one. To this type of learning Collazos, et al. (2001) call it collaborative (cooperative) learning and define it as: the instructional use of small groups in such a way that students work together to maximize their own learning and that of others, when this happens, collaborative skills are stimulated giving way to a meaningful learning environment that can be framed in two possibilities, as expressed by Álvarez, et al. (2005, p. 3) "group, allowing teamwork, two or more students working on the same problem at the same time, or an asynchronous work system, a space based on authorization."

Collaborative learning enhances a series of group and individual skills that are essential for the teacher's practice. According to Collazos et al. (2014) individual collaborative skills range from communication and interaction with others, active listening, speaking in turns, accepting diversity, sharing, exchanging and synthesizing ideas, expressing opinions and feelings, to giving support and support to others. In this same manner, group skills are developed such as: the ability to plan cooperatively, self-regulate, self-organize and make team decisions.

The use of ICT does not guarantee collaborative learning, but rather the mastery of them, this is because ICT are facilitators of informational and communicative processes. According to Leiva (2002, p. 5) "ICTs have enhanced collaborative learning and have made it possible for them to become multicultural, but we must not forget that new technologies are a mere instrument to achieve an end". For this reason, it is important to mention that ICTs facilitate collaborative work, provided that they are integrated to the processes in an appropriate way.

\subsection{MOODLE: THE EDUCATIONAL PLATFORM FOR TEACHER TRAINING}

Taking into account that the information society demands in teachers technological skills and collaborative skills in the exercise of teaching, it is necessary to use a modality that facilitates the teacher in training to make the transition from the conventional to the technological in a way less traumatic as the b-learning model offers, added to this, it is essential to implement strategies that allow academic 
collaboration, this is where Moodle with the GNU General Public License, is an abbreviation of dynamic and modular object-oriented learning environment, which plays a decisive role as a platform designed for collaborative learning.

Moodle offers the teacher the possibility of designing and managing online courses, developing different types of activities such as quizzes, forums and deliverable homework, embedding material from other sites, inserting audio and video files, managing study groups, online grading, monitoring the learning process and provide feedback through rubrics.

Considering that the information society demands digital and collaborative skills within the teaching practice, it is necessary to use tools that allow the transition from conventional to technological in a less traumatic way, as allowed by the b-learning model, added to this, it is essential to implement didactic strategies that allow strengthening teamwork, it is here where Moodle plays a decisive role as it is a platform designed for collaborative learning. Therefore, online trainings through Moodle offer an encouraging prospect for acquiring digital skills and collaborative skills

\subsection{STATEMENT OF THE PROBLEM}

In Colombia, the Computadores para Educar program (CPE) was created in 2000 with the purpose of facilitating access to ICTs for public educational institutions, and since then the Colombian Government has tried that teachers incorporate ICT into the curriculum. In order to achieve this goal, in the 2018-2022 National Development Plan the government was committed to promote the transformation of teaching practices with the support of ICT, leading many Universities including the UPC to support face-to-face education with virtual learning environments (VLE), creating without a good planning conditions so that teachers without further training could work on some subjects of the curriculum using b-learning through Moodle, as is the case of subjects such as critical care, mental health, biochemistry, computer science I, among others.

On the other hand, there are the students who continually complain about the lack of support from teachers through the Moodle platform and the lack of resourcefulness when updating or modifying the contents and activities within these spaces, giving as a result, the increase in academic plagiarism in the activities presented by the students and their apathy for deepen into the topics required in the different subjects supported by the VLEs, resulting in desertion or fails in virtual subjects, as evidenced in the subject Cátedra upecista during the second period 2019-2, the academic dropout exceeded 55\% and Cátedra de negocios exceeded $48 \%$ in the same period.

Given all this evidence, it became necessary to develop and implement a training process called "Docente Virtual Moodle", which implied the assumption of two roles: teacher and student, to try to solve 
the shortcomings in terms of technological training and achieve the collaborative work of teachers in the construction of academic activities.

For all the above, the following question arose: ¿What is the perception of higher education teachers regarding the development of technological skills and collaborative skills after training in blearning modality?

\section{IMPLEMENTATION}

\subsection{METHOD.}

Taking into account that the objective of the research was to determine the impact on the perception of the UPC teachers caused by the training mediated by Moodle, to know the potentialities and difficulties regarding the development of technological and collaborative skills, in order to improve the planning future trainings for teachers. The data necessary to study the problem is quantitative. This study was defined as a pre-experimental investigation with a pretest-posttest design with one group.

The research is defined as pre-experimental because it was impossible to implement some type of control over the sample (Valenzuela and Flores, 2012), the participating teachers responded to an open training call, but without any type of obligation, which prevented the creation of several groups.

The foregoing determined a descriptive study level for the research, without the pretense of explaining each construct itself, what was sought was to know the perception of the teachers regarding the possible influence of one on the other. According to Cauas $(2010$, p. 6), the level of descriptive studies "is directed essentially to the description of social or educational phenomena in a specific temporary and special circumstance, their questions are focused on the variables of the subjects or the situation".

\subsection{PARTICIPANTS.}

UPC teachers, who instruct at least one subject in the b-learning mode. From this population, it was selected a sample of 39 teachers from the surgical instrumentation, nursing and education programs, aged between 38 and 52 years, with a postgraduate level of studies and a majority of the female gender, through the call of the training courses called Docente Virtual Moodle.

\subsection{INSTRUMENTS.}

Two questionnaire-type instruments were constructed and validated through the triple entry table, categorizing the research constructs and their indicators. The first questionnaire sought through 18 questions to know the initial status of teachers regarding the use and appropriation of ICT and their collaborative skills. The second questionnaire with 59 questions sought to identify the skills and attitudes 
of teachers towards ICT and collaborative work after training.

\subsection{DATA COLLECTION.}

To achieve the objective of the research, the study was divided into four phases:

First phase: the theoretical bases of reference that framed the study were determined, socialization of the strategy to the academic directives of the faculty of health and education, publication of the call on the main page of the University. As a result, four groups of teachers were formed by free and direct enrollment, two from the surgical instrumentation program, one from the nursing program and one from the education program. The initial instrument was applied to learn about the level of use of technology and collaborative skills in higher education by the participants.

In the second phase, a constructivist approach was used through project-based learning, which according to Heredia and Sánchez (2013) allow the development of a product over a period of time through the exploration of situations from different perspectives while the project is being built. In this stage, the virtual Moodle teacher training was carried out, with a face-to-face meeting every week during the first month, where the teachers assumed the role of students, which later became a meeting every 15 days for two and a half months where the participants took on the role of teachers and began to incorporate ICT in one of the courses they had in the current academic load during that period.

At the end of the training, the second instrument was applied as part of the third phase including tabulation, coding, quantification, and evaluation regarding the integrity of the data.

In the fourth phase, the results were analyzed by comparing the initial sample and the final sample, in order to establish whether the training implemented fostered the development of digital and collaborative skills in teachers, showing its reflection in the teaching of the educator.

The data analysis was carried out using quantitative techniques, with a descriptive level of analysis due to its exploratory scope, due to the complexity of the population, with the purpose of establishing comparisons and providing answers to the research hypotheses (Hernández et al., 2014). Frequencies and percentages were used to represent the opinions of the teachers regarding each item, the arithmetic mean to determine the average opinion, the mode to observe the recurring opinion and the standard deviation to establish the trend of opinions. After the information from both instruments was tabulated, interpretations of the results were made and the comparisons that were necessary in this study were established. In order to perform the data analysis, the STATA statistical program was used. 


\section{FINDINGS}

To establish whether virtual training through MOODLE developed collaborative and digital skills in educators, and if there was a change in teaching, it was necessary to organize the information into categories to explain the findings:

Training in b-learning through Moodle. Although at the beginning of the research the selected teachers used the VLEs, only $5 \%$ had a notion of what the word b-learning implied, but in general, none of them clearly knew its definition. At the end of the training (view table 1), 70\% admitted that it favored their learning and $100 \%$ mentioned that it influenced their teaching process, and they prefer to be trained under the b-learning modality, due to time and mobility, and it allows them to perceive the advantages of education face-to-face and virtual education (view table 2).

Table 1. Level of knowledge about Moodle.

What does the term Moodle refer to?

A software that helps you learn better.

A system that revolutionizes the way of studying.

A technological strategy that allows teachers to integrate ICT into their work.

A LMS.
Frequency

$25,00 \%$

$25,00 \%$

$45,00 \%$

$5,00 \%$

Table 2. Teachers' opinion regarding the use of ICT in academic management and their ongoing training.

\begin{tabular}{|c|c|c|c|c|c|}
\hline Ítems & $\begin{array}{l}\text { Completely } \\
\text { agree }\end{array}$ & Agree & Undecided & Disagree & $\begin{array}{l}\text { Completely } \\
\text { disagree }\end{array}$ \\
\hline $\begin{array}{l}\text { The course through Moodle allowed me to design } \\
\text { feedback strategies with my students through the } \\
\text { network. }\end{array}$ & $30,00 \%$ & $70,00 \%$ & $0,00 \%$ & $0,00 \%$ & $0,00 \%$ \\
\hline Online courses enhance my learning process. & $0,00 \%$ & $70,00 \%$ & $15,00 \%$ & $15,00 \%$ & $0,00 \%$ \\
\hline $\begin{array}{l}\text { Ideally, the courses should be partly online and } \\
\text { partly face-to-face. }\end{array}$ & $50,00 \%$ & $50,00 \%$ & $0,00 \%$ & $0,00 \%$ & $0,00 \%$ \\
\hline
\end{tabular}

Technological skills. Although $100 \%$ of the teachers frequently accessed the Internet, and $80 \%$ had their own laptop, they did not show mastery of digital educational tools, $90 \%$ were limited to the use of word processors and presentations, $65 \%$ of the teachers considered that between $40 \%$ and $60 \%$ integrated ICT into their classes, limiting themselves to YouTube videos and Prezi and SlideShare presentations. (view figure 1) 
Figure 5. ICT that teachers frequently use to support their classes.

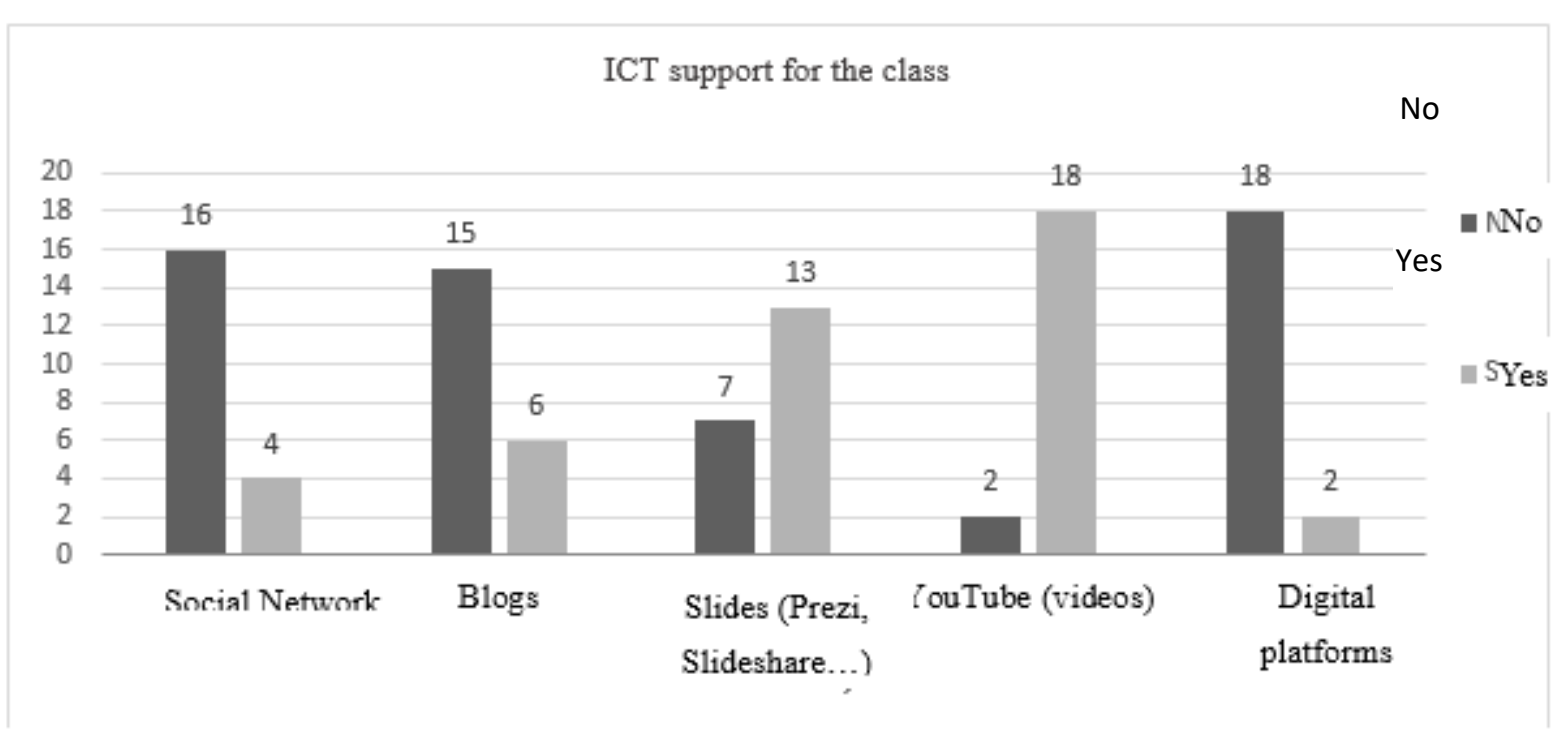

(Data collected by the author).

At the end of the training, $100 \%$ of the teachers showed more knowledge and a better attitude about the use of ICT in the teaching process, $85 \%$ of the teachers argued that they knew different ways and methods to search the Internet for information and download it, 75\% learned to use social networks and blogs as a teaching strategy (view table 3), 100\% of the participants in the study learned to use the computer to support their classes and their administrative management and in terms of didacticmethodological matters, it was evidenced that the $90 \%$ of teachers build learning activities that involve the use of technology in their elaboration (View table 4).

Table 3. Teachers' opinion regarding the functional and creative use of standard instrumental software.

\begin{tabular}{|c|c|c|c|c|c|}
\hline Item & Completely agree & Agree & Undecided & Disagree & $\begin{array}{c}\text { Completely } \\
\text { disagree }\end{array}$ \\
\hline $\begin{array}{l}\text { I know several ways and } \\
\text { methods to search the web } \\
\text { the information I need. }\end{array}$ & $50,00 \%$ & $35,00 \%$ & $15,00 \%$ & $0,00 \%$ & $0,00 \%$ \\
\hline $\begin{array}{c}\text { I know to get information } \\
\text { from digital libraries and } \\
\text { online repositories. }\end{array}$ & $20,00 \%$ & $50,00 \%$ & $15,00 \%$ & $15,00 \%$ & $0,00 \%$ \\
\hline $\begin{array}{l}\text { I know how to download } \\
\text { information and use it in } \\
\text { documents and } \\
\text { presentations. }\end{array}$ & $35,00 \%$ & $50,00 \%$ & $15,00 \%$ & $0,00 \%$ & $0,00 \%$ \\
\hline $\begin{array}{l}\text { I design and edit } \\
\text { presentations to support my } \\
\text { classes. }\end{array}$ & $50,00 \%$ & $35,00 \%$ & $0,00 \%$ & $15,00 \%$ & $0,00 \%$ \\
\hline
\end{tabular}


I can build databases and use Excel tools.

Table 4. Teachers' opinion regarding the integration of ICT in the daily teaching and learning processes of the classroom and the use of these to facilitate communication, expression, access to all students, and address their diversity.

\begin{tabular}{|c|c|c|c|c|c|}
\hline Item & $\begin{array}{l}\text { Completely } \\
\text { agree }\end{array}$ & Agree & $\begin{array}{l}\text { Undecide } \\
\qquad d\end{array}$ & Disagree & $\begin{array}{l}\text { Completely } \\
\text { disagree }\end{array}$ \\
\hline I use ICT in all my classes. & $35,00 \%$ & $35,00 \%$ & $15,00 \%$ & $15,00 \%$ & $0,00 \%$ \\
\hline $\begin{array}{l}\text { In my classes, the use of ICT (slides, } \\
\text { videos, among others) is mandatory } \\
\text { for all my students. }\end{array}$ & $50,00 \%$ & $40,00 \%$ & $0,00 \%$ & $10,00 \%$ & $0,00 \%$ \\
\hline $\begin{array}{l}\text { The technologies I use the most are } \\
\text { PowerPoint and YouTube videos. }\end{array}$ & $5,00 \%$ & $15,00 \%$ & $0,00 \%$ & $40,00 \%$ & $40,00 \%$ \\
\hline $\begin{array}{l}\text { I use social media to maintain } \\
\text { academic communication outside of } \\
\text { the classroom. }\end{array}$ & $5,00 \%$ & $95,00 \%$ & $0,00 \%$ & $0,00 \%$ & $0,00 \%$ \\
\hline $\begin{array}{l}\text { The platform as a mediator of my } \\
\text { class would facilitate the delivery of } \\
\text { tasks and their feedback. }\end{array}$ & $100,00 \%$ & $0,00 \%$ & $0,00 \%$ & $0,00 \%$ & $0,00 \%$ \\
\hline $\begin{array}{l}\text { A discussion forum would be a very } \\
\text { useful tool in communicating with } \\
\text { my students. }\end{array}$ & $75,00 \%$ & $25,00 \%$ & $0,00 \%$ & $0,00 \%$ & $0,00 \%$ \\
\hline $\begin{array}{c}\text { The digital platform favors student } \\
\text { learning. }\end{array}$ & $90,00 \%$ & $10,00 \%$ & $0,00 \%$ & $0,00 \%$ & $0,00 \%$ \\
\hline $\begin{array}{l}\text { The digital platform facilitates the } \\
\text { use of resources to support the class, } \\
\text { more dynamic and enriching for } \\
\text { students. }\end{array}$ & $90,00 \%$ & $10,00 \%$ & $0,00 \%$ & $0,00 \%$ & $0,00 \%$ \\
\hline $\begin{array}{l}\text { I would like to have a virtual } \\
\text { platform to support my class. }\end{array}$ & $95,00 \%$ & $5,00 \%$ & $0,00 \%$ & $0,00 \%$ & $0,00 \%$ \\
\hline
\end{tabular}

Collaborative skills. At the beginning, $65 \%$ of the teachers gave the responsibility for making a decision to the team leader and in addition to this (view table 5), 60\% did not like to work together. At the end of the research (view table 6), $85 \%$ of the teachers showed a good attitude towards teamwork and towards the active participation. The same percentage recognized that training through Moodle allows to acquire skills to implement collaborative and communication strategies and they admitted that Moodle encourages collaborative work and that it facilitates the construction of courses or subjects online in a collaborative way (view table 7). 
Table 5. Teachers' opinion regarding the question: in a work team it is very important to meet the objectives. Who should make the decisions?

\begin{tabular}{lc}
\multicolumn{1}{c|}{ Item } & Percentage \\
\hline The leader because he is the only responsible. & $65 \%$ \\
The authority that has created the team. & $15 \%$ \\
By vote, the largest vote wins. & $20 \%$ \\
\hline
\end{tabular}

Table 1. Teachers' opinion regarding the question: The way you feel better when doing a job is...

\begin{tabular}{lc}
\hline \multicolumn{1}{c}{ Item } & Percentage \\
\hline As a team but let someone else be the leader (I don't like that responsibility). & $20 \%$ \\
As a team, but being the leader & $20 \%$ \\
Alone, without the pressures of dealing with the opinion of others. & $60 \%$ \\
\hline
\end{tabular}

Tabla 2. Teachers' opinion regarding group collaborative skills stimulated in training.

\begin{tabular}{|c|c|c|c|c|c|}
\hline Item & $\begin{array}{l}\text { Completely } \\
\text { agree }\end{array}$ & Agree & Undecided & Disagree & $\begin{array}{l}\text { Completely } \\
\text { disagree }\end{array}$ \\
\hline $\begin{array}{l}\text { My participation in work teams is } \\
\text { greater when they are virtual teams }\end{array}$ & $0,00 \%$ & $40,00 \%$ & $25,00 \%$ & $35,00 \%$ & $0,00 \%$ \\
\hline $\begin{array}{c}\text { I participate more in group or } \\
\text { teamwork when they are face to } \\
\text { face. }\end{array}$ & $20,00 \%$ & $15,00 \%$ & $25,00 \%$ & $40,00 \%$ & $0,00 \%$ \\
\hline $\begin{array}{l}\text { From the course through Moodle, I } \\
\text { can apply collaborative learning } \\
\text { strategies, communication and } \\
\text { feedback with my students using } \\
\text { ICT. }\end{array}$ & $30,00 \%$ & $70,00 \%$ & $0,00 \%$ & $0,00 \%$ & $0,00 \%$ \\
\hline
\end{tabular}

\section{CONCLUSIONS}

When a teacher wishes to combine their face-to-face classes with VLEs, it is necessary for them to identify how the student perceives an educational platform and what fears it may generate, being positive that teachers are trained by initially assuming an active role as a student, which leads them to look at mediation with ICT from another perspective. In the same way, by assuming the role of student and teacher, in both scenarios, which is, in face-to-face meetings with VLEs, this is the case through Moodle, where they acquire technological and collaborative skills that allow them to carry out consistent activities to the needs of 21 st century students.

Teachers, when assuming the roles in question, discover that, although the technological environment is appropriate, and has all the necessary tools, if the teacher does not use their creativity and the technological and collaborative skills acquired in the training to update or modify the contents and the activities, the student will not feel connection with the educational process, which generates apathy, resulting in the lack of acquisition of the competencies proposed within the educational process 


\section{REFERENCES}

Alfaro, J. A. (2010). Competencia para el trabajo colaborativo (objeto virtual de aprendizaje). Recuperado de: http://www.ruv.itesm.mx/convenio/tabasco/oas/tc/homedoc.htm

Álvarez, I., Ayuste, A., Gros, B., Guerra, V. y Romañá, T. (2005). construct knowledge with technological support for collaborative learning. Revista Iberoamericana de Educación (OEI), 1(36), 1-15. http://diposit.ub.edu/dspace/handle/2445/58103

Cauas, D. (2010). Definition of the variables, focus and type of research. Red universitaria de aprendizaje, 1(1), 1-11. http://www.rua.unam.mx/objeto/7985/definicion-de-las-variables-enfoque-y-tipo-deinvestigacion

Collazos, C., Guerrero, L. y Vergara, A. (2001). Collaborative learning: a change in the role of teacher. Presentation presented in the proceedings of the 3rd seminar on Computer Science education, Punta Arenas, Chile. http://terras.edu.ar/jornadas/102/biblio/102Aprendizaje-Colaborativo.pdf

Collazos, C., Muñoz, J. y Hernández, Y. (2014). Collaborative learning supported by Computer. [Versión Iniciativa Latinoamericana de Libros de Texto Abiertos LATIn]. http://latinproject.org/books/Aprendizaje_colaborativo_apoyado_por_computador_CC_BY-SA_3.0.pdf

Comisión de las Comunidades Europeas. (2006). Proposal for a recommendation of the European Parliament and of the Council on the creation of the European qualifications framework for lifelong learning. https://ec.europa.eu/ploteus/sites/eac-eqf/files/broch_es.pdf

Heredia, Y. y Sánchez, A. (2013). Theories of learning in the educational context. Monterrey, México: Digital publishing: Tecnológico de Monterrey.

Hernández, R., Fernández, C. y Baptista, P, (2014). Research Methodology, Sixth Edition. México D.F, México: publishing house McGraw Hill interamericana.

Gómez, M. (2000). Qualitative and quantitative content analysis: Definition, classification and methodology. Journal of Human Sciences. Technological University of Pereira. http://www.utp.edu.co/ chumanas/revistas/revistas/rev20/gomez.htm

Leiva, A. (2002). ICT and collaborative learning. Revista Digital Sociedad de la Información, 33(1), 1-9. http://www.sociedadelainformacion.com/33/colaborativo.pdf

Molano, D. (2013). It is still necessary for ict to be an economic engine. Money Magazine, (sección: especial comercial), 1 de marzo de 2020. http://www.dinero.com/edicion-impresa/especialcomercial/articulo/aun-falta-para-tic-sean-motor-economico/177002

Moodle. (2014). About Moodle. Retrieved from the Moodle Community portal: https://docs.moodle.org/all/es/Acerca_de_Moodle

OEI (2013). Skills and dexterity in a person. https://www.eoi.es/blogs/madeon/2013/05/21/habilidadesy-destreza-en-una-persona/

Paradiso. (2015). What are Virtual Learning Platforms?. https://www.paradisosolutions.com.co/plataformas-virtuales-aprendizaje 
Ramírez, M. (2011). Triple input box for building open learning object instruments. http://catedra.ruv.itesm.mx/handle/987654321/367

Rodríguez, M. y Rodríguez, L. (2008). Investigation methodology. Part 7: Data analysis. Retrieved on March 7, 2020, from the Website of the Faculty of Economic Sciences and Administration of the University of the Republic in Uruguay. http://www.ccee.edu.uy/ensenian/catmetinvcont/material/PPT\%20Parte\%207\%20Analisis\%20de\%20los $\% 20$ datos-1.pdf

Semana. (2014). Universities: a crisis about to explode. SEMANA Magazine [online]. December 6, 2014. [Date consulted: March 7, 2020]. http://www.semana.com/nacion/articulo/universidades-una-crisispunto-de-explotar/411398-3

UNAM (s.f.). Matrix of Digital Skills. recovered from https://educatic.unam.mx/publicaciones/matrizhabilidades-digitales.html

Valenzuela, J. y Flores, M. (2012). Foundations of Educational Research, Volume 2 and 3. Monterrey, México: Digital publishing: Tecnológico de Monterrey. 